\title{
Viscoelastic Indentation Contact Mechanics Applied to the Rheological Characterization in Micro-Scales
}

\author{
Mototsugu SAKAI \\ Dept. Materials Science, Toyohashi University of Technology, \\ Tempaku-cho, Toyohashi
}

\begin{abstract}
The indentation contact hardness has long been utilized in various engineering fields as well as in scientific studies, since the pioneering works conducted by A. Martens (1898), J.A.Brinell (1900), and E. Meyer (1908). The upsurges of electronics, and computer science and engineering in 1980s lead to the development of instrumented micro/nanoindentation test systems that enable to examine the mechanical properties (elastic modulus, yield strength, hardness, etc.) in micro/nano-scales. These conventional test systems, however, can only measure the indentation load $P$ and penetration depth $h$ hysteresis relation $(P-h$ relation) in a precise manner, and then estimate the mechanical properties through the elastic assumptions to approximate the indentation contact area $A$ at the indentation load $P$. The present indentation contact mechanics, therefore, cannot be applied to very ductile materials, time-dependent-viscoelastic materials, as well as coating/substrate composite materials, for this elastic assumption/approximation is by no means applied to these nonlinear materials. The author invented a novel instrumented indentation test system, the indentation microscope, that is capable of measuring the in-situe contact area $A$ along with $P$ and $h$, allowing the rheological characterization of monolithic as well as composite materials with any linear/nonlinear deformation and flow. In the present feature article, the author addresses the viscoelastic indentation contact mechanics, including the principle, theoretical considerations, and the applications.
\end{abstract}

Key Words: Indentation contact mechanics / Hardness / Elasticity / Plasticity / Viscoelasticity / Indentation microscope / Micro/nano-rheology

\section{粘弾性圧子力学の構築とミクロ領域におけるレオロジー計測}

\author{
逆井 基次
}

(原稿受理 : 2010 年 10 月 19 日)

\section{1. 緒言}

固体力学や連続体力学の学問体系は橋梁や航空機等に代 表される構造物の設計のみならず高機能化を目的とした材 料設計・開発においても不可欠かつ重要な役割を演じてい る。一方, 近年に拈けるミクロ・ナノ科学・工学の隆盛は MEMS (Micro Electro Mechanical System) に代表される極微小 構造物の開発および実用化を加速させつつあり, 微小構造 物設計に関わる信頼性·寿命評価技術の確立, 更には材料の 高機能化を目的とした微小領域における材料物性の定量的 評価解析技術の確立が重要な課題となりつつある.

1980 年代に始まるエレクトロニクスおよびコンピュータ の目覚しい技術的発展は, 極微小変位 $(\sim 1 \mathrm{~nm})$ ならびに極微 小荷重 $(\sim 1 \mu \mathrm{N})$ を計測可能とする各種の高性能計測プローブ や計測機器類の開発ならびに，これらの市場への提供を可

豊橋市天伯町雲雀ヶ丘

豊橋技術科学大学 物質工学系

E-mail: msakai@tutms.tut.ac.jp
能とした。 その結果, ミクロ・ナノ領域における力学物性計 測技術の進展ならびに物性研究は活況を呈しつつある。各 種の手法がミクロ・ナノ力学物性計測に適用されているが, これらの中でとりわけ，ダイアモンド微小圧子を用いた計 測手法が，その簡便性により，広く用いられている。しかし， 圧子を材料に圧入する過程で誘起される圧子直下での極め て複雑な応力・歪み場が, 材料物性の定量評価を拒む大きな 壁ともなっている。この問題は, 刺激速度依存性や時間依 存性を示す粘弾性材料の物性評価において特に深刻となる ため, 圧子力学手法のこの分野への浸透·認知度は低い.

著者達は微小領域における圧子圧入に関わる力学 (Indentation Contact Mechanics) を「圧子力学」と称し, 弾性・ 弾塑性・粘弾性領域において, その学問としての体系化, こ れを適用したミクロ・ナノ領域における力学物性の定量, な らびに，そのための新規計測装置開発を進めてきた ${ }^{1-30)}$ 本論 文では粘弾性圧子力学に焦点を絞り,その「原理」と「応用」 を俯瞰する。 


\section{2. 圧子力学の歴史背景 ${ }^{31}$}

球圧子を用いた材料物性の評価・研究に関する歴史は 1850 年代まで遡る，英国に端を発する産業革命を支えた蒸気機関 の発明, そして蒸気機関車の実用化に伴い, 鋳鉄更には鋼 鉄の材料としての高機能化に関する研究が始まる。特に蒸 気機関車用軌道 (鋳鉄·鋼鉄材) と車輪との間で生じる接触 損傷やせん断き裂の問題は 1850 年代には既に大きな問題と なっており, 接触力学 (Contact Mechanics) 研究進展への工学 的期待が増しつつあった，幸いにして，当時は数理弾性論 の体系化に向けた歴史的なうねり (upsurge) が押し寄せてい た時期とも合致していたため, 多くの天才的数学者・物理学 者が接触力学に関しても多大なる興味を示し，また大きな 功績を残した. 球体の接触力学は H. Hertz (1881)により最初 の数学的体系化がなされ, 更に, J. Businesque (1885) は, よ り一般的な軸対称回転体の接触力学問題を論じた。両名の 極めて革新的な研究成果は一世紀以上を経た今日における 圧子力学の数学的体系の基礎となっている. 球形圧子の圧 入により生じる塑性圧痕のサイズとその際に用いられた圧 入荷重とから材料の圧入抵抗性として「硬度（圧子硬度）」 を実験で求める研究はA. Martens (1898) に端を発し, J.A. Brinell (1900)により精密化が図られた。彼が定義した Brinell 硬度は現時点においても金属材料の硬度指数として広く用 いられている。圧子硬度が持つ材料力学的な意味, すなわち, 力学物性值としての硬度に関する考察は E. Meyer (1908) に端 を発している. Meyer は圧入荷重 $P$ を, これにより生じた圧 痕の正射影面積 $A_{\text {proj }}$ で除した值として圧子硬度 (Meyer 硬度, $\left.H_{\mathrm{M}}=P / A_{\text {proj }}\right)$ を定義することが硬度の材料力学的・物理的な 意味を考察する上で本質的に重要であることを球圧子なら びに円錐圧子に関する理論考察から示した．球形圧子では 高硬度材料の塑性変形を的確に計測することが難しいため,

R. Smith と G. Sandland (1923) の研究を基に 1925 年に Vickers 社が設立され, 現在, 硬度測定に最も多用されている四面 ピラミッド圧子（Vicker 圧子；面傾き角度 $\beta=22.0^{\circ}$ ）を装着 した硬度計が開発された

延性の著しい金属材料の降伏応力 $Y$ と Meyer 硬度 $H_{\mathrm{M}}$ との 間に $H_{\mathrm{M}} \approx 3 Y$ (Marshの関係式) なる実験式の成立する事実 は既に 1930 年頃までに明らかにされていた． L. Prandtl (1920) は「2 次元すべり線場理論」を提唱し Marshの関係式に理論 的な基礎を与えた。 これ以降現在に至るまで,「圧子硬度は 降伏応力の約 3 倍で与えられる」という呪文（?）が一人 歩きし, その結果, 「圧子硬度は塑性の尺度である」との誤っ た固定概念が硬度の材料学的・物理学的解釈に混乱をもたら し続けている. $H_{\mathrm{M}} \approx 3 Y$ なる関係式は塑性·延性が極めて著 しい金属材料にのみ適用できるものであり, 高分子材料や セラミックス材料には全く適用できない. D. Tabor (1951) は 脆性的な金属材料やセラミック材料において圧子荷重除荷 時に圧痕の著しい弾性回復の生じる現象に着目し, Meyer 硬 度に普遍的かつ材料力学的・物理学的に有意な解釈を与える ことに尽力した，更には徐荷時の弾性回復に着目した弾性 率（ヤング率）の定量評価を可能とする精密な実験を行い, 現在の圧子力学発展への基礎を与えた。

1950 年代に入ると高分子粘弾性・レオロジーの理論·実験 研究が活況を呈し始め, その影響は圧子力学にも及び始め る. 粘弾性構成方程式のラプラス空間における表記が実空間
における完全弾性体の構成方程式の表記と等価になる良く 知られた事実に着目し，J.R.M. Radok (1958) は球接触問題に 関する Hertzの弾性方程式の逆ラプラス変換として, 球圧子 の粘弾性圧子力学理論を構築した. しかし, その実験的検証, 更には沉用のピラミッド圧子 (Vickers 圧子, Berkovich 圧子) に対する粘弾性圧子力学理論への拡張には, 高性能計測装 置の開発が不可欠であったため, 著者達による 1990 年代の 研究を待つ必要があった。

先にも述べたように 1980 年代に入るとエレクトロニクス 技術の急速な発展により高性能計測プローブやコンピュー 夕の利用が進み, 計装化ナノインデンテーション測定装置 の開発とこれらの市場への投入が開始され，ミクロ・ナノ 領域における弾性・弾塑性圧子力学実験研究が活況を呈する ようになり現在に至っている.

圧子として最も汎用性の高いピラミッド圧子（Vickers 圧 子, Berkovich 圧子）・円錐圧子に焦点を絞り，以下，粘弾性 圧子力学の理論および実験について論じる.

\section{3. 粘弾性圧子力学}

J.R.M. Radok (1957), E.H. Lee-J.M.R. Radok (1960) は「弾性 — 粘弾性対応原理」を用いHertzの球体接触に関する弾性論を 粘弾性圧子力学理論へと拡張した. ${ }^{32,33)}$ 筆者は円錐圧子に関す るSneddonの弾性解に「弾性 - 粘弾性対応原理」を適応し, Boltzmann 重畳積分型の粘弾性構成方程式を誘導した. ${ }^{6-10)}$

円錐圧子に関する Sneddonの弾性解は次式で与えられる： ${ }^{34)}$

$$
P=\frac{2 E^{\prime}}{\pi \tan \beta} h^{2}
$$

(1)式において $P, h$ および $\beta$ は, Fig. 1 に示すように, それぞれ, 圧子の圧入荷重, 圧入深さ, および圧子の面傾き角度を示す (これらは全て実測可能物理量である)。また，弾性率 $E^{\prime}$ は ヤング率 $E$ およびポアッソン比 $v$ を用い $E^{\prime}=E /\left(1-v^{2}\right)$ により 定義される．圧子の材質は通常ダイアモンドであるため, (1) 式において, 圧子は剛体と仮定され, その弾性変形は考慮さ れていない. 弾性 - 粘弾性対応原理および Boltzmann 重畳積 分を (1) 式に適用することにより, 半無限線形粘弾性体平面 に円錐圧子を圧入する際の力学応答は次式で表される. ${ }^{6-10)}$

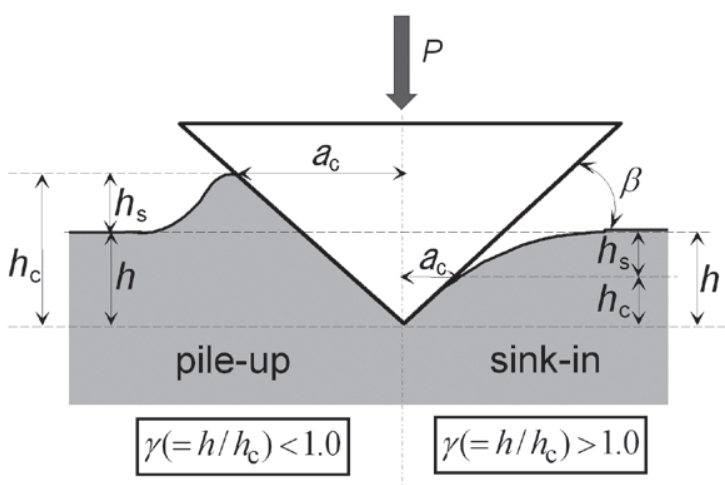

Fig. 1. The geometrical profiles of indentation contact, and the characteristic contact parameters. 


$$
P(t)=\frac{2}{\pi \tan \beta} \int_{0}^{t} E^{\prime}\left(t-t^{\prime}\right)\left[\frac{d h\left(t^{\prime}\right)^{2}}{d t^{\prime}}\right] d t^{\prime}
$$

あるいは，

$$
h(t)^{2}=\frac{\pi \tan \beta}{2} \int_{0}^{t} D^{\prime}\left(t-t^{\prime}\right)\left[\frac{d P\left(t^{\prime}\right)}{d t^{\prime}}\right] d t^{\prime}
$$

(2), (3) 式において $P(t)$ および $h(t)$ はそれぞれ時間依存型の 圧入荷重と圧入深さを意味する。また， $E^{\prime}(t)$ および $D^{\prime}(t)$ は 時間依存型ポアッソン比 $v(t)$ を含む, 応力緩和弾性率およ びクリープコンプライアンス関数である.

\section{1 圧入深さ一定の条件下で生じる荷重緩和 ${ }^{6-10)}$}

粘弾性体平面にステップ状の圧入を加えた際の力学応答 として生じる荷重緩和現象について考える. 深さ $h_{0}$ のステッ プ状の圧入は Heaviside 関数 $H(t)$ を用い, $h\left(t^{\prime}\right)=h_{0} H\left(t^{\prime}\right)$ によ り表すことが出来るので，与式を (2) 式に代入し, 更に $H(t)$ の一次導関数が Dirack's delta 関数となることに留意すると次 式を得る：

$$
P(t)=\frac{2 h_{0}^{2}}{\pi \tan \beta} E^{\prime}(t)
$$

すなわち, 実測可能な荷重緩和 $P(t)$ から容易に応力緩和弾 性率 $E^{\prime}(t)$ を求めることが出来る.

\section{2 圧入荷重一定条件下で生じるクリープ变形 6-10)}

時間に依存しない一定の圧子圧入荷重 $P_{0}$ をステップ状に 粘弾性平面に付加した場合には $P\left(t^{\prime}\right)=P_{0} H\left(t^{\prime}\right)$ を(3) 式に代 入することにより

$$
h(t)^{2}=\frac{\pi \tan \beta}{2} P_{0} \cdot D^{\prime}(t)
$$

したがって，一定圧入荷重下で時間と共に増大する圧入ク リープにおいて, 実測可能な圧入深さの二乗, $h(t)^{2}$, からク リープコンプライアンス関数 $D^{\prime}(t)$ を容易に求めることが出 来る.

\section{3 定速度圧入条件下での力学応答 6 -10)}

圧入速度 $\left(k_{\mathrm{h}}\right)$ が一定, すなわち, $h\left(t^{\prime}\right)=k_{\mathrm{h}} \cdot t^{\prime}\left(t^{\prime}>0\right)$ で 円錐・ピラミッド圧子を圧入したときの力学応答は与式を (2) 式に代入することにより

$$
P(t)=\frac{4 k_{\mathrm{h}}^{2}}{\pi \tan \beta} \int_{0}^{t} E^{\prime}\left(t-t^{\prime}\right) t^{\prime} d t^{\prime}
$$

となる.さらに (6) 式に Laplace 変換を適用し, 最終的に,

$$
E^{\prime}(t)=\frac{\pi \tan \beta}{4 k_{\mathrm{h}}{ }^{2}}\left[\frac{d^{2} P(t)}{d t^{2}}\right]
$$

が得られる。すなわち, 定速度圧入試験で得られる増加型 荷重の時間に関する 2 階の導関数から応力緩和関数を決定 することが出来る。

\section{4 定速度荷重付加条件下での力学応答 ${ }^{6-10)}$}

3.3 項では圧入速度を一定としたが, 円錐・ピラミッド圧 子に付加する荷重速度を一定とした粘弾性試験, すなわち, $P\left(t^{\prime}\right)=k_{\mathrm{p}} \cdot t^{\prime}$, の場合, 与式を(3) 式に代入し, 前項と同様な 演算を行うことにより

$$
D^{\prime}(t)=\frac{2}{k_{\mathrm{P}} \pi \tan \beta}\left(\frac{d[h(t)]^{2}}{d t}\right)
$$

が得られる。定速度荷重付加試験においては, したがって, 力学応答としての圧入深さの二乗, $h(t)^{2}$, の 1 階導関数から クリープコンプライアンス関数が得られる.

Fig. 1 に示すように圧子と材料表面との接触幾何形状 (sinkin, pile-up) は材料の物性に依存し極めて複雑となる，本節で 述べた粘弾性圧子力学理論は, 弾性圧子力学を基礎として いるため，そこには円錐・ピラミッド圧子と粘弾性平面との 接触で生じる接触面積に関する重大な仮定・近似が内在して おり, 上述の理論体系を粘弾性関数の計測・評価に適用する 上では大きな問題がある。更に, 円錐・ピラミッド圧子の場 合, 圧子先端部応力場の特異性（圧子先端部直下に誘起され る応力が無限大に発散する事実）のため, 実測される圧入深 さ $h(t)$ には粘弾性変形に起因するもののみではなく, 局所 高応力場で誘起される「塑性変形」が含まれる.したがって, 上記の理論式を実測粘弾性量に適用すると, この塑性効果 により, 応力緩和弾性率は常に著しく過小に, クリープコ ンプライアンス関数は著しく過大に評価されてしまう。こ れらの重大な仮定・近似を用いない厳密な理論ならびにその 実用計測への適用を次節で詳述する。

\section{4. ミクロ領域におけるレオロジー関数計測への圧 子力学の適用}

\section{1 粘弾性圧子力学理論の精密化 ${ }^{35}$}

汎用のミクロ・ナノ計装化インデンテーション計測装置は 圧子の押し込み荷重 $P$ と押し込み深さ $h$ を定量計測するこ とが出来る。これらの実測值を基に各種の力学物性を定量 するためには, 実験では実測不可能な「接触面積 $A 」$ を近似 的に推算することが不可欠となる。このことが圧子法を用 いた力学物性定量の最弱点となっている.

弾性, 弾塑性, 粘弾性全ての領域において圧子の圧入過 程における力学応答は圧子荷重 $P$ と接触面積 $A$ との関係, すなわち「P-A関係」によって厳密に記述される。しかし ながら， $A$ の実測定量が不可能であるため, 前述した圧子力 学の長い歴史において, 常に, 圧子荷重 $P$ と実測可能な圧 入深さ $h$ との関係, すなわち $\lceil P-h$ 関係」と, 推算により 求めた $A$ から力学物性を論じることしか出来なかった。今 日に至る圧子力学が常に「P- $h$ 関係」として定式化され てきたのはこのためである. 球圧子に対する Hertzの弾性 解, $P \propto E^{\prime} h^{3 / 2}$, および円錐圧子に対する Sneddonの弾性解, $P \propto E^{\prime} h^{2}$ が広く用いられてきたのも接触面積 $A$ の実験的定量 が不可能であった事情が背景にある.

(1) 式で示す Sneddon の $P-h$ 弾性解は接触面積 $A$ が計測 不可能である事情に由来する「止む得ない」数式表現であ る. 弾性体への圧子圧入過程に関わる最も的確な表現は $P$ - $A$ 関係として次式により与えられる： 


$$
P=\frac{E^{\prime}}{2} \tan \beta \cdot A
$$

Fig. 1 に示す円錐圧子の接触半径 $a_{\mathrm{c}}$ により $A=\pi a_{\mathrm{c}}{ }^{2}$, 接触圧 入深さ $h_{\mathrm{c}}$ が圧子の面傾き角度 $\beta$ を用い $h_{\mathrm{c}}=a_{\mathrm{c}} \tan \beta$, 実測物 理量である押し込み深さ（圧子圧入深さ） $h$ を実測不可能な 接触圧入深さ $h_{\mathrm{c}}$ に関係付ける圧痕プロファイルルパラメター $\gamma$ を $h=\gamma h_{\mathrm{c}}$ によって定義しておくと，(9) 式から次式で表さ れる $P-h$ 関係を得る。

$$
P=\frac{\pi E^{\prime}}{2 \tan \beta} \frac{1}{\gamma^{2}} h^{2}
$$

弾性変形が支配的な領域においては圧痕は sink-in プロファ イル (Fig. 1 参照) を示し, その $\gamma$ 值は 1 より大きく $(\gamma>1.0)$, 逆に塑性変形の著しい領域における圧痕は pile-up プロファ イルを示し (Fig. 1 参照), $\gamma<1.0$ となる. 完全弾性体の場合, 圧痕は最も著しい sink-in を示し, $\gamma=\pi / 2$ (Love の解) で与え られる. ${ }^{34)} こ の$ 值を (10) 式に代入したものが (1) 式で与えられ た Sneddonの $P-h$ 弾性解である.

以上の考察から容易に分かることであるが，前節の粘弾 性圧子力学の定式化（(1)～(8) 式参照）は圧痕プロファイ ルとして常に sink-in を仮定し，さらに $\gamma=\pi / 2$ で与えられる 一定值を仮定している。この仮定は塑性変形の無視できな い一般的な弾塑性材料や時間依存性を示古粘弾性材料. 粘弾 塑性材料において致命的な欠点となる. 事実, 多くの高分 子粘弾性材料に円錐・ピラミッド圧子を適用した場合, 圧痕 プロファイルルパラメターは, $\gamma<\pi / 2$ かつ時間依存性を持つ, すなわち， $\gamma(t)$ として表現されなければならず，前節の圧子 力学定式化に本質的な変更をもたらす，換言すると，時間依 存型の圧痕プロファイルパラメター $\gamma(t)$ の実験的な知見が得 られない限り, 汎用の計装化ミクロ・ナノインデンテーショ ン計測装置で求まる $P(t)-h(t)$ 関係からは如何なる粘弾性 パラメータもしくは粘弾性関数も「定量的」に決定するこ とは出来ない.

一方, 粘弾性領域において, 圧子の圧入過程での接触面 積の時間依存性 $A(t)$ を定量評価することが可能であるなら ば, (9) 式の粘弾性表記として

$$
P(t)=\frac{\tan \beta}{2} \int_{0}^{t} E^{\prime}\left(t-t^{\prime}\right) \frac{d A\left(t^{\prime}\right)}{d t^{\prime}} d t^{\prime}
$$

あるいは, (11) 式の補完表記として

$$
A(t)=\frac{2}{\tan \beta} \int_{0}^{t} D^{\prime}\left(t-t^{\prime}\right) \frac{d P\left(t^{\prime}\right)}{d t^{\prime}} d t^{\prime}
$$

を得る. 前述の $(1) \sim(8)$ 式は接触面積 $A(t)$ が計測不可能で ある事情に由来する「止む得ない」数式表現であり，そこ には圧痕形状の弾性解に起因する近似や仮定を含む致命的 な問題が内在していることを既に述べた。一方，(11) およ び (12) 式は接触面積 $A(t)$ に基づく構成式であり，この種の 近似や仮定を何ら含んでおらず，したがって応力緩和弾性 率 $E^{\prime}(t)$ やクリープコンプライアンス関数 $D^{\prime}(t)$ の実験的定量 に威力を発揮する。 ポアッソン比等, 圧痕形状に影響を与
える全ての力学環境からの帰結として得られる接触面積 $A(t)$ が圧入荷重 $P(t)$ を，あるいは $P(t)$ が $A(t)$ を定量的に記述し ていることを(11) および(12) 式は表現している.

\section{2 接触面積定量のための顕微インデンテーション計測 装置の開発 ${ }^{23-26,28,35)}$}

本節では圧子の圧入過程における接触面積 $A(t)$ を $P(t)-$ $h(t)$ 関係と併せて同時定量可能な新規計装化装置, 計装化顕 微インデンテーション計測装置（顕微インデンター），の開 発と性能について述べる. Fig. 2 に顕微インデンターの概要 と, その外観を示す。また，圧子接触画像計測原理（明視 野法と暗視野法）を Fig. 3 に示す。多くの場合, 暗視野法で 接触画像の計測を行っているが, より鮮明な接触画像を得 るためには試験体の光学的透過率あるいは反射率を考慮の うえ，明視野法あるいは暗視野法を選択する必要がある。

純銅への四面ピラミッド圧子 $\left(\beta=45^{\circ}\right)$ の繰り返し圧入 徐荷過程における $P-h$ 曲線および圧子接触画像（明視野 像）を Fig. 4 に示す. ${ }^{25)}$ また、ゾル - ゲル法で合成したメチ

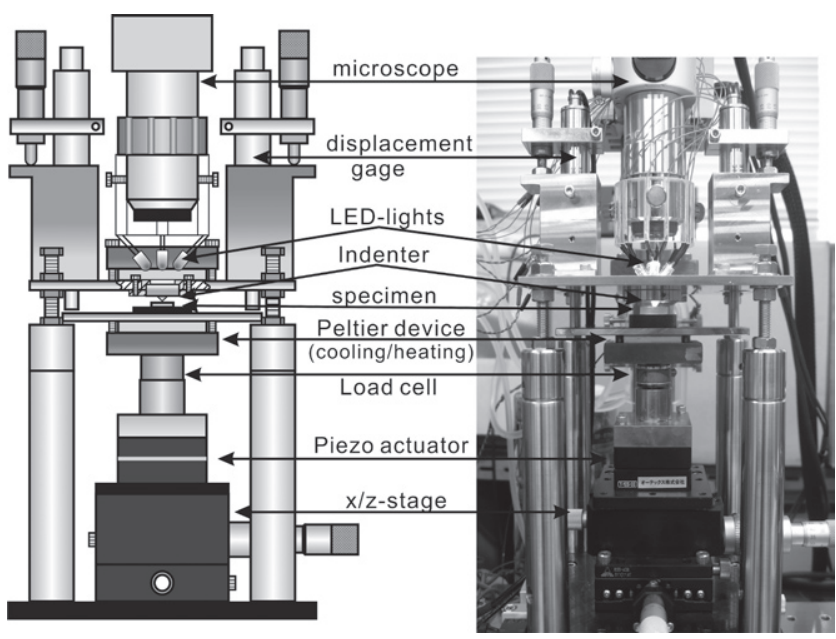

Fig. 2. Details of the instrumented indentation microscope. (a) Bright-field viewing

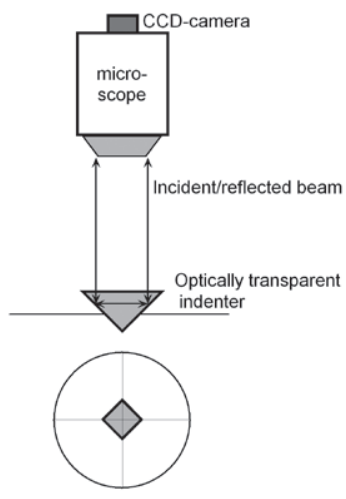

Bright-field image (b) Dark-field viewing

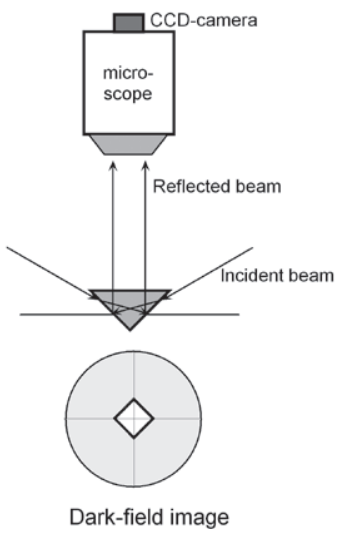

Fig. 3. Principle of (a) the bright-field and (b) the dark-field viewings of the indentation microscope. 
ルシルセスキオキサン $\left(\mathrm{MeSiO}_{3 / 2}\right)$ をポリカーボネート基板 上にコーティングした膜 / 基板複合体（膜厚 $t_{\mathrm{f}}=10 \mu \mathrm{m} ）$ 一 の Berkovick 圧子の繰り返し圧入 - 徐荷過程における $P-h$ 曲線およびその際の圧子接触画像 (暗視野像) を Fig. 5 に示 す ${ }^{28)}$ Fig. 4 および Fig. 5 に例示したように, 沉用の計測装置 で実測不可能であった接触面積 $A$ をその場同時計測するこ とが出来るため, 厳密に各種の力学物性值を定量評価するこ とが出来る. Fig. 6 には顕微インデンターにより実測された $P-A$ プロット（負荷 - 除荷履歴線）の例を示す. 負荷過程 での直線の勾配から Meyer 硬度 $H_{\mathrm{M}}(=P / A)$ を, 除荷線初期の 勾配 $\left(E^{\prime} \tan \beta / 2\right)$ 加弾性率 $E^{\prime}$ を直接かつ厳密に求めること ができる。このようにして求めた各種の工学材料の弾性率 $E^{\prime}$ と慣用の超音波法で求めた值との相関を Fig. 7 に示す。両 者の間に極めて優れた等価性が認められる.

用いる光学ビームの波長が顕微インデンターを用いた接 触面積あるいは接触半径の計測精度を左右する。このため現 状, 圧痕計測長の精度は約 $500 \mathrm{~nm}$ が限界となっている。し たがって, 顕微インデンターを用い, 上述の解析手法に則り, 計測された接触面積から高精度で力学物性を定量するため には, 圧痕寸法は最小でも 1 2 $\mu \mathrm{m}$ 以上となることが好まし い.この事実は, 顕微インデンターによる接触面積計測に 可視光ビームを用いる限り, ナノ領域での計測が不可能で あることを意味している. ${ }^{23-25)}$

圧子除荷後に残留する圧痕面積 (残留圧痕面積) $A_{\mathrm{r}}$ を光学 顕微鏡等で計測することにより慣用の硬度測定は行われてき た。上述した圧子圧入時に同時計測される接触面積 $A$ と $A_{\mathrm{r}}$ との間には, 圧子の除荷時に生じる弾性回復により, 有 限の差異が存在し, 常に $A_{\mathrm{r}} \leq A$ となる. 差異の程度は次節で 述べる塑性尺度 $\left(E^{\prime} \tan \beta / Y\right)$ に依存するが, $\left(A-A_{\mathrm{r}}\right) / \mathrm{A} \leq 0.1$ と
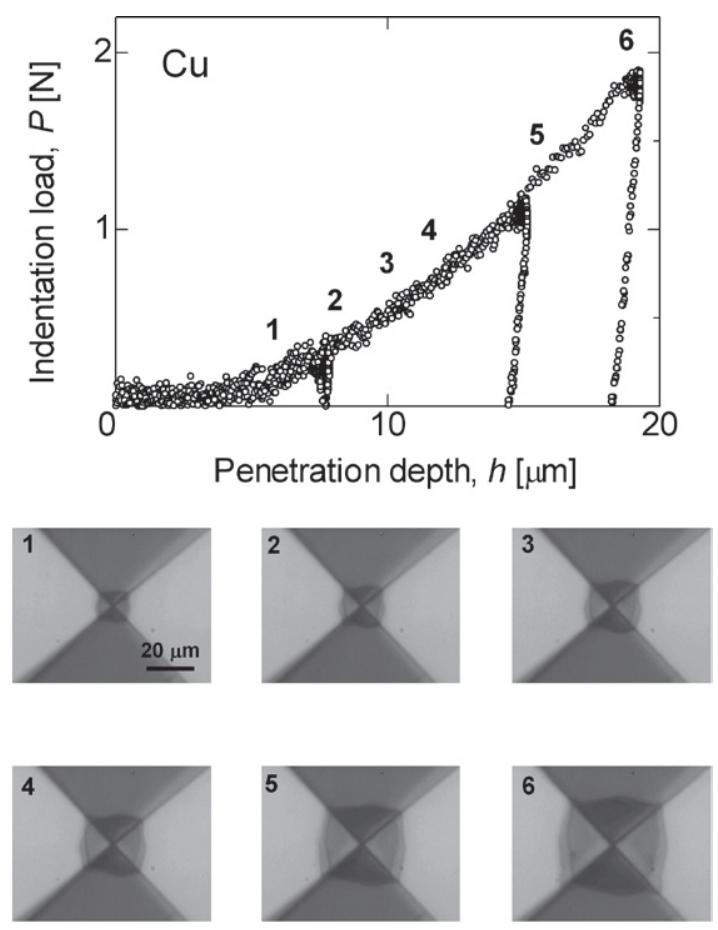

Fig. 4. Indentation load $P$ versus penetration depth $h$ hysteresis of a metallic copper with the in-situ bright-field images of the contact profiles of impression at the locations numbered in the $P-h$ diagram.
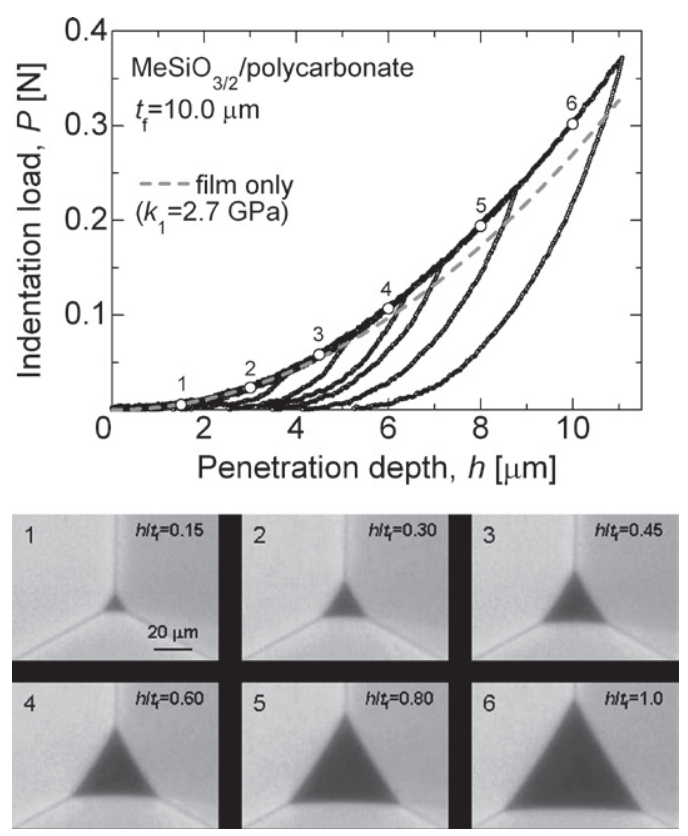

Fig. 5. Indentation load $P$ versus penetration depth $h$ hysteresis of a $\mathrm{MeSiO}_{3 / 2}$ film with its thickness of $t_{f}=10.0 \mu \mathrm{m}$ coated on a polycarbonate substrate with the in-situ dark-field images of the Berkovich contact profiles of impression at the locations numbered in the $P$ - $h$ diagram.

(a)

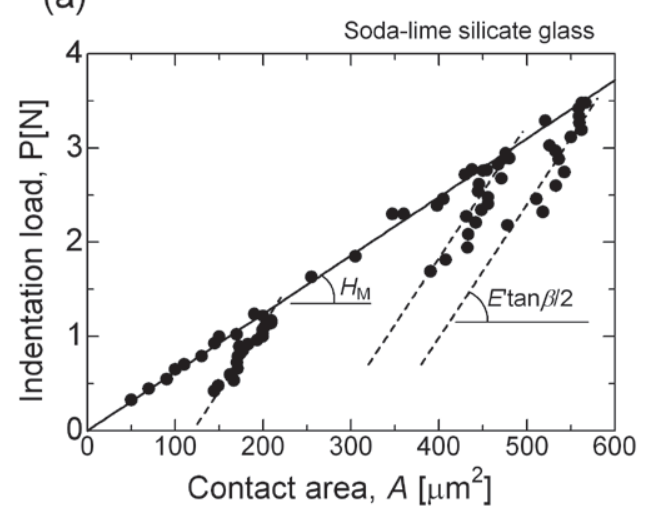

(b)

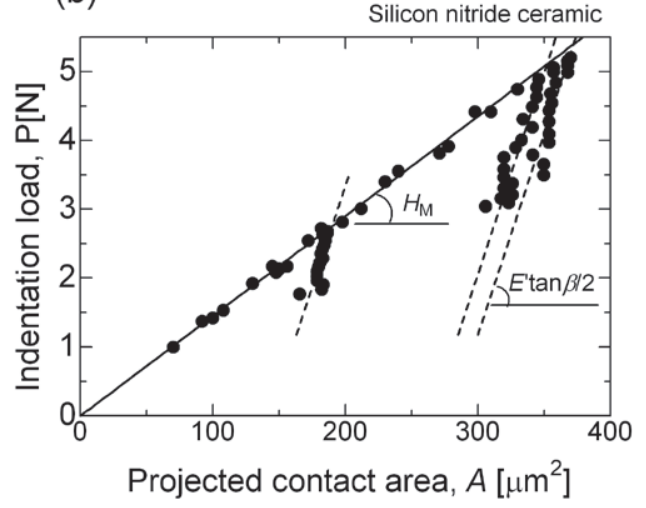

Fig. 6. Indentation load $P$ versus contact area $A$ hystereses of (a) a sodalime silicate glass, and (b) a silicon nitride ceramic. 
なることが実験あるいは有限要素を用いた数值解析により 明らかにされている。

機械加工技術の限界として, 汎用のダイアモンド圧子（例 えばダイアモンド Berkovich 圧子）の先端は理想的な鋭角を 形成しているわけではなく，曲率半径が約 $200 \mathrm{~nm}$ の球ある いは回転楕円形状をしている。このため, ナノ領域の圧子力 学実験においては, この非理想形状を補正するための「面積 補正関数」をあらかじめ実験的に求めておく必要がある. ${ }^{31)}$ 上 述の顕微インデンターを用いた実験および解析においても， 面積補正関数の概念は重要ではあるが，先に述べたように， 用いる可視光ビームの波長により現状の顕微インデンターの 適用領域がミクロ領域に限定されているため, 面積補正を行 う必要は無く, ピラミッド圧子形状を規定する面傾き角度 $\beta$ で一意的に圧子形状を定量的に記述することができる。

\section{3 塑性の定量 ${ }^{35)}$}

粘弾性領域において圧子力学データから定量的に各種の 粘弾性パラメータや粘弾性関数を求めるためには, 円錐・ピ ラミッド圧子直下の高応力場で誘起される塑性変形の定量・ 分離が不可欠となる。粘弾塑性領域での考察に先立ち, 先 ず弾塑性領域において顕微インデンターを用いた塑性変形 の定量分離手法について概要を示す.

弾性率 $E^{\prime}$ および降伏応力 $Y$ (歪み効果を有する場合には代 表降伏応力 $Y_{\mathrm{R}}$ ) を有する弾塑性体を考える。この弾塑性体 に荷重 $P$ で圧子を圧入した際に生じる接触面積を $A$ とする. この弾塑性体とは別に, 上記弾性率 $E^{\prime}$ を有する完全弾性体 (すなわちその降伏応力 $Y$ は無限大), および上記の降伏応 力 $Y$ を有する完全塑性体 (すなわちその弾性率 $E^{\prime}$ (は無限大), をそれぞれ考える. 同一の圧入荷重 $P$ をこれらの完全弾性 体および完全塑性体に付加した際に生じる接触面積をそれ ぞれ， $A_{\mathrm{e}}$ (添え字 $\mathrm{e}$ は elastic の意味）および $A_{\mathrm{p}}$ (添え字 $\mathrm{p}$ は plastic の意味）とする. Sneddonの弾性解（(9) 式）より

$$
A_{\mathrm{e}}=\frac{2}{E^{\prime} \tan \beta} \cdot P
$$

完全塑性体に対する Marsh 式 $\left(H_{\mathrm{M}}=\mathrm{C} \cdot \mathrm{Y}\right)$ を変形し, 表面拘 束係数 $(\mathrm{C}=2.6 \sim 3.0)$ を用い,

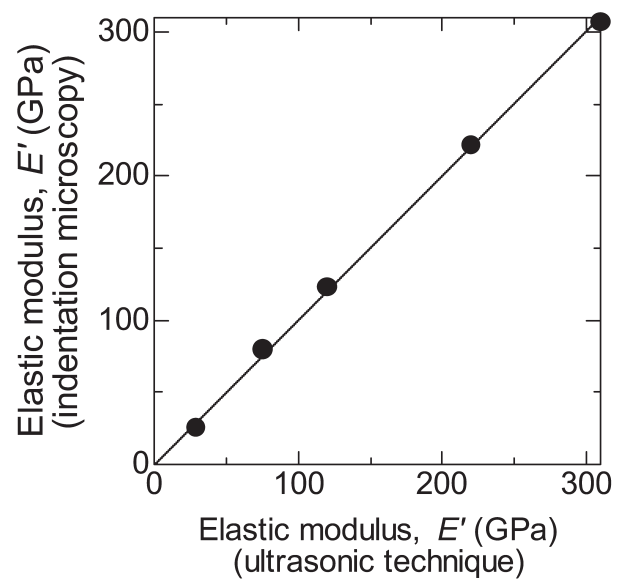

Fig. 7. One-to-one correlation of the elastic moduli of various engineering materials measured in the indentation and the ultrasonic tests.

$$
A_{\mathrm{p}}=\frac{P}{C \cdot Y}
$$

と表すことが出来る。また，上記の弾塑性体の圧入荷重 $P$ における接触面積 $A$ は Meyer 硬度の定義を書き換えた表現 式として,

$$
A=\frac{P}{H_{\mathrm{M}}}
$$

で与えられる。

次のステップとして，上記の完全弾性体と完全塑性体の 両者の特性を具備している先に想定した弾塑性体の接触面 積 $A$ は (13), (14) 式で定義された $A_{\mathrm{e}}$ および $A_{\mathrm{p}}$ と如何なる関 係で結び付けられるかを考える。圧子の圧入荷重 $P$ に対し て弾塑性体内部で弾性変形と塑性変形が相互作用すること なくそれぞれ独立に応答するならば,

$$
A=A_{\mathrm{e}}+A_{\mathrm{p}}
$$

の成立が予想される。(16) 式の妥当性に付いては今のとこ ろ解析的に精査することが不可能であるため, ANSYSを用 いた弾塑性有限要素法により, 数值解として, その妥当性, 換言すると，弾性変形 - 塑性変形間の力学的相互作用を検 討した結果を Fig. 8 に示す。Fig. 8 には (16) 式を破線で示し てある。図から分かるように弾性 - 塑性相互作用の存在に より (16) 式で仮定した等価性は成立していない，弾塑性接 触面積 $A$ は弾性接触面積 $A_{\mathrm{e}}$ と塑性接触面積 $A_{\mathrm{p}}$ との和, $A_{\mathrm{e}}$ $+A_{\mathrm{p}}$, より常に小さく, 弾性変形が支配的となる領域 $\left(A_{\mathrm{p}} / A_{\mathrm{e}}\right.$ $\left.\left(\equiv E^{\prime} \tan \beta / 2 \mathrm{CY}\right)<0.1\right)$ と塑性変形が支配的となる領域 $\left(A_{\mathrm{p}} / A_{\mathrm{e}}\right.$ $\left.\left(\equiv E^{\prime} \tan \beta / 2 \mathrm{CY}\right)>100\right)$ においてのみ $A \approx A_{\mathrm{e}}+A_{\mathrm{p}}$ の関係が成り 立つ。したがって, (16) 式を補正するために, 現象論的な弾 性 - 塑性相互作用補正因子 $f$ を次式で導入する；

$$
f=\frac{A}{A_{\mathrm{e}}+A_{\mathrm{p}}}
$$

この補正因子は, Fig. 8 に示す破線と実践との比により表さ れるものであり，その半経験的表現は次式で与えられる；

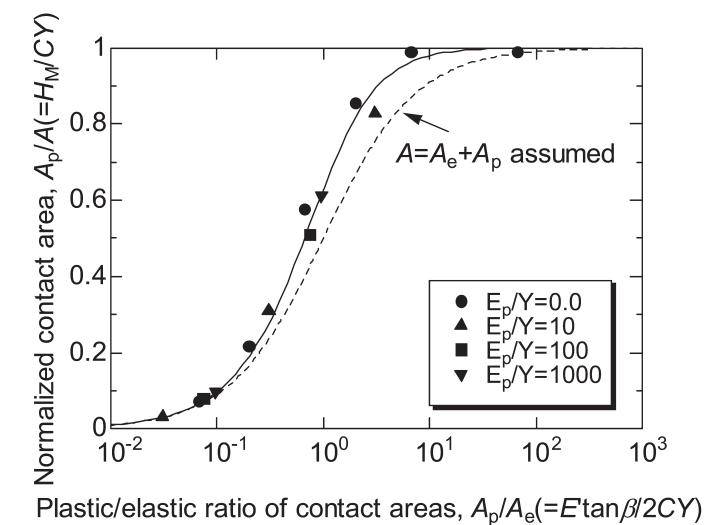

Fig. 8. Non-dimensional plots of the contact areas of $A_{\mathrm{p}} / A$ versus $A_{\mathrm{p}} / A_{\mathrm{e}}$. The effect of strain-hardening is dictated by the hardening modulus, $E_{\mathrm{p}}{ }^{18)}$ 


$$
f=\frac{\left(1+1 / x^{3 / 2}\right)^{2 / 3}}{1+1 / x}
$$

(18) 式で $x$ は塑性変形の尺度 (plasticity index) を表しており

$$
x=\frac{A_{\mathrm{p}}}{A_{\mathrm{e}}}\left(\equiv \frac{E^{\prime} \tan \beta}{2 C \cdot Y}\right)
$$

によって定義される。(18) 式で与えられる補正因子 $f$ と塑性 尺度 $x\left(=A_{\mathrm{p}} / A_{\mathrm{e}}\right)$ の関係を Fig. 9 に示す（有限要素法の結果を もとに，表面拘束係数として $C=2.65$ を用いた)．Fig. 9 に 示すように, $A_{\mathrm{p}} / A_{\mathrm{e}} \approx 1.0$, すなわち弾性変形の寄与 $A_{\mathrm{e}}$ と塑性 変形の寄与 $A_{\mathrm{p}}$ が同程度 $\left(A_{\mathrm{e}} \approx A_{\mathrm{p}}\right)$ となる場合に弾性 - 塑性相 互作用が最も大きく, 弾性領域 $A_{\mathrm{p}} / A_{\mathrm{e}}<<1.0$ および塑性領域 $A_{\mathrm{p}} / A_{\mathrm{e}} \gg 1.0$ では相互作用による補正は無視できるようにな る,すなわち, $f \approx 1.0$ となる.

(13)，(14)，および (17) 式を用いることにより弾性接触面 積 $A_{\mathrm{e}}$ は

$$
A_{\mathrm{e}}=\frac{A}{f}-\frac{P}{C \cdot Y}
$$

によって表すことができ，顕微インデンターにより実測さ れる接触面積 $A$ と降伏応力 $Y$ に関係付けられる。一方, 実 測不可能な塑性接触面積 $A_{\mathrm{p}}$ を,

$$
A_{\mathrm{p}}=\frac{A}{f}-\frac{P}{\frac{1}{2} E^{\prime} \tan \beta}
$$

により，更に (20b) 式に (14) 式を代入することにより，降伏 応力 $Y$ を次式により実測量 $P$ および $A$ を用いて決定するこ ともできる：

$$
Y=\frac{P}{C \cdot\left(\frac{A}{f}-\frac{P}{\frac{1}{2} E^{\prime} \tan \beta}\right)}
$$

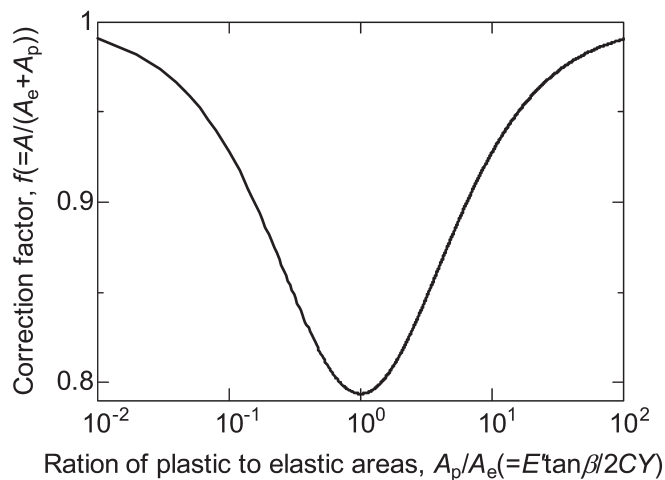

Fig. 9. The correction factor $f$ plotted against the plastic/elastic ratio of contact area. (20a)，(20b) および (21) 式を適用するに当たって必要となる 弾性率 $E^{\prime}$ は 4.2 節および Fig. 6 で示した $P-A$ 除荷線の勾配 から容易にかつ厳密に求めることが出来る。しかし, (18), (19) 式を用いて $f$ を決定するためには, 降伏応力 $Y$ が既知である 必要がある。これに付いては，先ず，適当な $Y$ 值を仮定し， Fig. 9 より零次近似として $f$ を求め, これを(21) 式に適用し て求めた $Y$ 值を再度 Fig. 9 に適用し, 新たに 1 次近似として の $f$ 值を決定する。この操作を繰り返すことにより $f, Y$ ，そ して $A_{\mathrm{e}}$ と $A_{\mathrm{p}}$ を厳密に決定することができる，注目する弾塑 性材料が歪み効果を示す場合には，顕微インデンターにより 実測した接触面積 $A$ を上記の操作に適用して決定された降

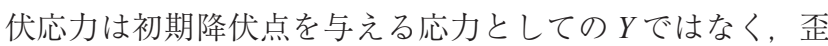
み効果を反映した代表降伏応力 $Y_{\mathrm{R}}$ となる。本節で述べた弾 塑性圧子力学における塑性変形量の定量とこれに基づく降 伏応力 $Y$ の決定手法は著者により新規に提案されたもので あり, 次節で述べる粘弾性関数の定量においても極めて重 要な役割を演じる. ${ }^{35)}$

\section{4 計装化顕微インデンテーション計測装置を用いた粘 弾性関数の定量 ${ }^{35}$}

鋭角圧子の圧入により, 多くの粘弾性材料には粘弾性変 形·流動のみならず，圧子直下の高応力場による塑性変形も 誘起される。したがって，粘弾性関数の定量においては，こ の塑性変形の定量的な分離が不可欠となる。また，接触面 積にも時間依存性が現れるため，先に述べたように沉用の ミクロ・ナノインデンテーション計測装置では, 粘弾性関数 の定量計測は不可能である。

顕微インデンターで実測される時間依存性接触面積 $A(t)$ から塑性変形に伴う寄与を除去することにより求まる粘弾 性接触面積を $A_{\mathrm{ve}}(t)$ とすると, (11), (12) 式は, それぞれ, 次式を用いて書き換えることができる：

$$
\begin{aligned}
& P(t)=\frac{\tan \beta}{2} \int_{0}^{t} E^{\prime}\left(t-t^{\prime}\right) \frac{d A_{\mathrm{ve}}\left(t^{\prime}\right)}{d t^{\prime}} d t^{\prime} \\
& A_{\mathrm{ve}}(t)=\frac{2}{\tan \beta} \int_{0}^{t} D^{\prime}\left(t-t^{\prime}\right) \frac{d P\left(t^{\prime}\right)}{d t^{\prime}} d t^{\prime}
\end{aligned}
$$

前節で示した弾塑性領域における弾性接触面積 $A_{\mathrm{e}}$ の表現式, (20a) 式, は時間依存型粘弾性領域においては弾性接触面積 $A_{\mathrm{e}}$ が粘弾性接触面積 $A_{\mathrm{ve}}(t)$ となることに留意し, 次式のよう に書き換えられる： ${ }^{35)}$

$$
A_{\mathrm{ve}}(t)=\frac{A(t)}{f}-\frac{P(t)}{C \cdot Y}
$$

代表的な静的刺激一応答における $A_{\mathrm{ve}}(t)$ と, これに対応する 粘弾性関数の表現式を Table I およびTable II にまとめて示す.

非晶質セレン $(\mathrm{Se})$ (ガラス転移温度： $T_{\mathrm{g}}=30.0^{\circ} \mathrm{C}$ ) を例に, 顕微インデンテーション計測装置を用いて，Table I に示した 荷重緩和およびクリープ試験に関する解析手法に則って求め た静的粘弾性関数 (応力緩和弾性率 $E^{\prime}(t)$ とクリープコンプ ライアンス関数 $\left.D^{\prime}(t)\right)$ を Fig. 10 および 11 に, それぞれ示す(各 温度で求めた粘弾性曲線ならびに時間温度換算則を用い，標 準温度 $\left(T_{\mathrm{s}}=30^{\circ} \mathrm{C}\right)$ で重ね合わせを行ったマスター曲線). ${ }^{35)}$ マ スター曲線図中の破線は $E^{\prime}(t)$ と $D^{\prime}(t)$ との補完関係式, 


$$
\int_{0}^{t} E^{\prime}\left(t^{\prime}\right) D^{\prime}\left(t-t^{\prime}\right) d t^{\prime}=t
$$

あるいはそのラプラス空間における表現式, $\bar{E}(s) \bar{D}(s)=1 / \mathrm{s}^{2}$, を用い，実測された $E^{\prime}(t)$ に関するマスター曲線から算出し た $D^{\prime}(t)$ ， あるいは $D^{\prime}(t)$ に関するマスター曲線から算出した $E^{\prime}(t)$ を，それぞれ，示す。良好なる両者の一致は本論文で 紹介した顕微インデンターを用いた粘弾性関数の定量・定 式化に自己整合性のあることを示すものである.

一方, 短冊状試験片 $\left(1 \times 1 \times 3 \mathrm{~mm}^{3}\right)$ を用いた慣用圧縮 試験（巨視的試験）の結果を Fig. 10 および 11 のマスター曲 線図に実線で示す. 圧子力学試験 (微視的試験) 結果と巨 視的試験結果の間に有意差の存在することが分かる。特に, 短時間領域において, 微視的試験結果は巨視的試験結果に 比べ, 粘弾性変形流動に加速効果のあることを示している. 今後微構造との関連で更なる検討を要する興味深い結果で ある。

Table I. Viscoelastic stimulus-response diagrams and their constitutive equations

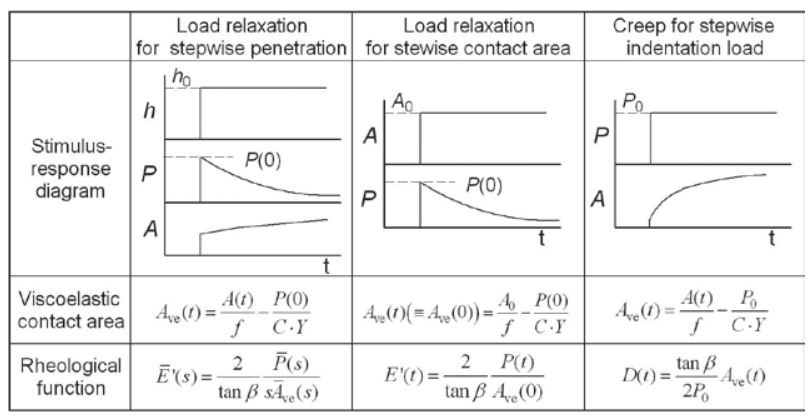

${ }^{*} \bar{E}(s), \bar{P}(s), \bar{A}_{\mathrm{ve}}(s)$ are the Laplace-tranceformed $E^{\prime}(t), P(t), A_{\mathrm{ve}}(t)$

Table II. Viscoelastic stimulus-response diagrams and their constitutive equations

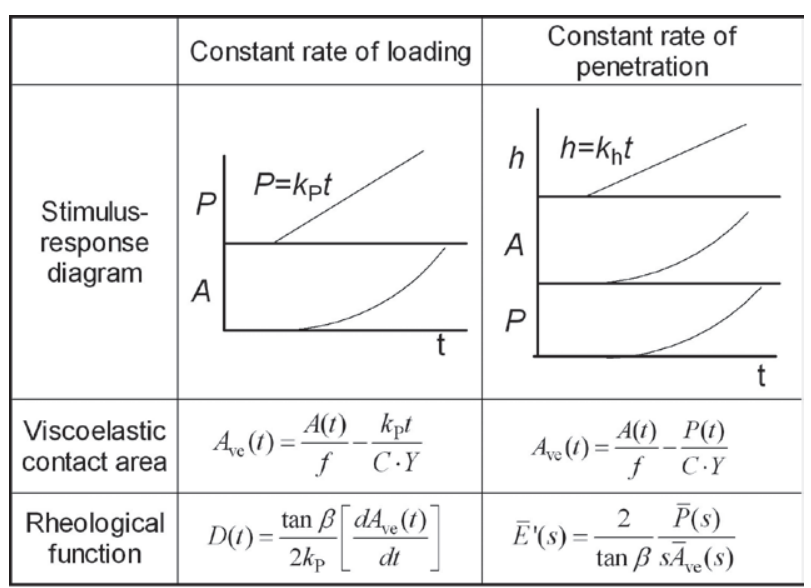

${ }^{*} \bar{E}^{\prime}(s), \bar{P}(s), \bar{A}_{\mathrm{ve}}(s)$ are the Laplace-tranceformed $E^{\prime}(t), P(t), A_{\mathrm{ve}}(t)$

\section{5. 結語}

慣用の計装化ミクロ・ナノインデンテーション計測装置 は圧子圧入荷重 $P$ と圧入深さ $h$ の関係 $(P-h$ 関係 $)$ を定量 計測することができ，弾性・弾塑性領域における力学物性定 量に多大なる貢献をしてきた。しかしながら，力学物性定 量に不可欠な圧子と試験体表面との間に生じる「接触面積 $A\rfloor$ を実測することができないため，弾性近似法に則った推算に より接触面積を求める必要がある。一方, 塑性変形の著し い延性材料（多くの金属材料），膜/基板複合材料，および 時間依存性・速度依存性を示す粘弾性材料に, この弾性近 似を適用するが出来ない致命的な問題も存在する。 ミクロ. ナノ領域における力学物性定量を目的として，1980年代か ら急速な発展を遂げてきた圧子力学手法が高分子粘弾性の 分野で多用されていない現状は, 上記の致命的な問題に帰 せられる。

著者達により装置の開発がなされ，またこれを用いた力 学物性定量化のための解析手法と定式化が確立されつつあ る計装化顕微インデンテーション計測法は, 圧子圧入荷重 $P$, 圧入深さ $h$ と同時に接触面積 $A$ を同時定量計測することが できる. ${ }^{23-26,28,35)} P-A$ 関係の実測が可能となったことにより， 微小領域における全ての力学物性量（弾性, 弾塑性, 粘弾 塑性，‥) を厳密に定量評価することができるようになった。 今後は，顕微インデンテーション計測装置を用い，巨視的 力学物性と微視的力学物性の間に存在するであろう類似性・ 相違性を材料の微構造や分子構造と結び付けて解明してい く研究の進展が待たれる.

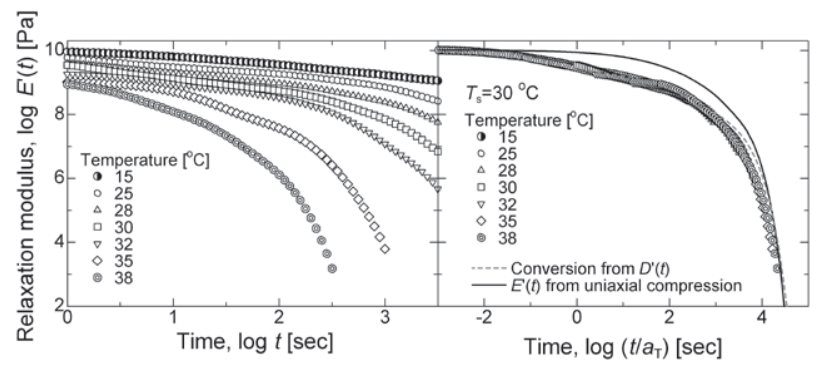

Fig. 10. The stress relaxation functions of an amorphous Se at the various temperatures of measurement, and their time-temperaturesuperposed master curve at the standard temperature of $30^{\circ} \mathrm{C}$.

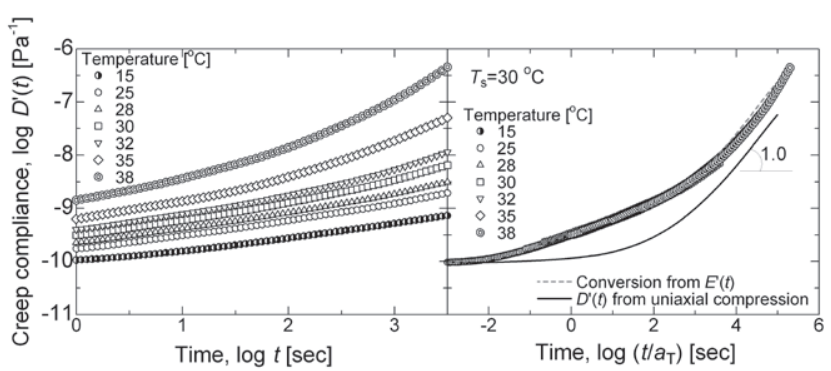

Fig. 11. Creep compliance functions of an amorphous Se at the various temperatures of measurement, and their time-temperaturesuperposed master curve at the standard temperature of $30^{\circ} \mathrm{C}$. 
高分子材料に代表される粘弾性体の圧子力学実験を念頭 に置いた場合，圧子と粘弾性体との間で生じる「粘着ある いは凝着接触問題」が科学的にもまた工学的にも重要とな る場合が多い. 球圧子に対する Hertz 接触のエネルギー論 に凝着エネルギーを組み込む形で構築された凝着接触理論 (Johnson-Kendall-Roberts 理論, Derjaguin-Muller-Toporov 理論) は, この分野においても, 圧子との接触面積（凝着面積） の定量が, 凝着力ならびに剥離挙動の定量に極めて重要と なることを示している. ${ }^{36,37)} こ の$ 観点からも，ミクロ領域にお ける凝着接触の実験研究において計装化顕微インデンテー ションマイクロスコープの優位性とポテンシャルは極めて 高いと言える.

\section{謝辞}

宮島達也氏（産業技術総合研究所）, 松田厚範氏（豊橋技 術科学大学), 武藤浩行氏 (豊橋技術科学大学), 羽切教雄氏 (豊 橋技術科学大学), ならびに多くの学生諸氏の協力により本 研究は遂行されました。

\section{REFERRENCES}

1) Sakai M, Acta Metall. Mater. 41, 1751-1758 (1993).

2) Nowak R, Sakai M, Acta Metall. Mater. 42, 2879-2891 (1994).

3) Sakai M, Hanyu H, Inagaki M, J. Am. Ceram. Soc. 78, 1006-1012 (1995).

4) Sakai M, Shimizu S, Ishikawa T, J. Mater. Res. 14, 1471-1484 (1999).

5) Sakai M, J. Mater. Res. 14, 3630-3639 (1999).

6) Shimizu S, Yanagimoto T, Sakai M, J. Mater. Res. 14, 4075-4086 (1999).

7) Sakai M, Shimizu S, Miyajima N, Tanabe Y, Yasuda E, Carbon, 39, 606-614 (2001).

8) Sakai M, Shimizu S, J. Non-Crystall. Solids, 282, 236-247 (2001).

9) Sakai M, Shimizu S, J. Am. Ceram. Soc. 85, 1210-1216 (2002).

10) Sakai M, Phil. Mag. A, 82, 1841-1849 (2002).

11) Sakai M, Nakano Y, Shimizu S, J. Am. Ceram. Soc. 85, 1522-1528 (2002).

12) Sakai M, Nakano Y, J. Mater. Res. 17, 2161-2173 (2002).
13) Sakai M, Akatsu T, Numata $\mathrm{S}$, Matsuda $\mathrm{K}$, J. Mater. Res. 18, 2087-2096 (2003).

14) Sakai M, J. Mater. Res. 18, 1631-1640 (2003).

15) Sakai M, Scrip. Mater. 51, 391-395 (2004).

16) Zhang J, Sakai M, Mater. Sci. Eng. A, 381, $62-70$ (2004).

17) Sakai M, Nakano Y, J. Mater. Res. 19, 228-236 (2004).

18) Sakai M, Akatsu T, Numata S, Acta Mater, 52, 2359-2364 (2004).

19) Sakai M, Zhang J. Matsuda A, J. Mater. Res. 20, 2173-2183 (2005).

20) Sakai M, Sasaki M, Matsuda A, Acta Mater, 53, 4455-4462 (2005).

21) Sakai M, Phil Mag. 86, 5607-5624 (2006).

22) Muto H, Yamada R, Matsuda A, Sakai M, Phil Mag. 86, 5643-5652 (2006).

23) Miyajima T, Sakai M, Phil Mag. 86, 5729-5737 (2006).

24) Sakai M, Hakiri N, J. Mater. Res. 21, 2298-2303 (2006).

25) Hakiri N, Sakai M, Miyajima T, J. Soc. Mater. Sci, Japan, 56, 510-515 (2007).

26) Pelletier CGN, Den Toonder JMJ, Govaert LE, Hakiri N, Sakai M, Phil Mag. 88, 1291-1306 (2008).

27) Sakai M, J. Mater. Res. 24, 831-843 (2009).

28) Hakiri N, Matsuda A, Sakai M, J. Mater. Res. 24, 1950-1959 (2009).

29) Sakai M, Surf. Coat. Tech. 204, 1247-1251 (2010).

30) Futami T, Ohira M, Muto H, Sakai M, Carbon, 46, 671-678 (2008).

31) Sakai M, Chap. 1 in "Micro and Nano Mechanical Testing of Materials and Devices", edited by Yang F and Li JCM, Springer, New York, 2008.

32) Radok JMR, Q. Appl. Math. 15, 198-202 (1957).

33) Lee EH, Radok JMR, J. Appl. Mech. 27, 438-444 (1960).

34) Sneddon IN, Int. J. Eng. Sci. 3, 47- 57 (1965).

35) Sakai M, Hakiri N, to be submitted to J. Mater. Res.

36) Johnson KL, "Contact Mechanics", Cambridge University Press, Cambridge, 1985.

37) Maugis D, "Contact, Adhesion and Rupture of Elastic Solids", Springer, Heidelberg, 2000. 